INFINITY-Jurnal Matematika dan Aplikasinya (IJMA)

Volume 1 | Nomor 2 | Maret|2021

\title{
Peramalan Volume Debit Air Kota Palopo Menggunakan Model ARIMA Deteksi Pencilan
}

\section{Dwi Risky Arifanti', Asrirawan ${ }^{2}$}

Corespondensi Author
Institut Agama Islam Negeri Palopo,
Palopo Indonesia
2Universitas Sulawesi Barat, Majene,
Indonesia

'[Email:dwi_risky_arifanti@iainpalopo.ac.id] 2[Email:asrirawan@unsulbar.ac.id]
Kata Kunci:

ARIMA; Pencilan, Jumlah Debit Air
Abstrak. Penelitian ini bertujuan untuk menentukan model peramalan yang sesuai untuk mengatasi adanya pencilan pada debit air Kota Palopo menggunakan model ARIMA deteksi pencilan. Penelitian ini menggunakan data debit air di Kota Palopo periode bulan Januari 2010 sampai dengan bulan Desember 2015 dengan jumlah data 72 yang diperoleh dari PT. PDAM Kota Palopo. Penelitian dimulai dengan mengindentifikasi model ARIMA dengan membuat plot data deret waktu, plot ACF, dan plot PACF, apabila pada tahap ini terlihat bahwa data masih belum stasioner pada varians, hal ini dapat diatasi dengan menggunakan transformasi box-cox, namun apabila data masih belum stasioner pada mean, maka perlu untuk dilakukan differencing pada data, kemudian dilanjutkan dengan mengestimasi parameter dengan Maximum Likelihood Estimation, menguji kenormalan galat menggunakan statistik uji Kolmogorov-Smirnov serta menguji kecukupan model menggunakan statistik uji Q, memilih model terbaik, hasil uji normalitas residual menunjukkan bahwa residual model ARIMA belum white noise, dan mengindikasikan adanya outlier pada data. Sehingga, langkah selanjutnya yang dilakukan adalah deteksi outlier untuk mengeliminasi efek outlier dan memperbesar ketepatan prediksi dari model ARIMA. Implementasi pemodelan ARIMA dan deteksi outlier dilakukan dengan menggunakan SAS. Peramalan dengan model ARIMA menghasilkan ARIMA $(1,1,1$,$) sebagai model$ terbaik, dengan nilai MSE 9579. Sedangkan model ARIMA dengan penambahan pencilan yaitu $64,72,70,58,52,50,61$.

\section{PENDAHULUAN}

Analisis deret waktu banyak digunakan dalam berbagai bidang, misalnya ekonomi, teknik, geofisik, pertanian dan kedokteran. Deret waktu adalah suatu deret observasi 
yang berurut dalam waktu. Analisis data deret waktu digunakan untuk melakukan analisis data yang mempertimbangkan pengaruh waktu. Data-data yang dikumpulkan secara periodik berdasarkan urutan waktu, bisa dalam jam, hari, minggu, bulan, kuartal dan tahun, dapat dilakukan analisis menggunakan metode analisis data analisis time series (Damayanti, 2008).

Wei (1994) mendefinisikan deret waktu sebagai deretan data atau amatan yang terurut berdasarkan waktu tertentu, dengan ketentuan memiliki selang waktu yang sama. Selang waktu tersebut dapat berupa harian, mingguan, bulanan, kuartal, bahkan tahunan. Sedangkan Bowerman et al (2005) mendefinisikannya sebagai deretan data atau amatan yang terurut pada variabel tertentu. Data deret waktu $Y_{t}$ dapat didefinisikan dengan $Y$ adalah suatu fungsi dari peubah bebas $t$, yang didapat dari suatu proses yang tidak diketahui model matematikanya. Dalam proses peramalan menggunakan data deret waktu, tidak melibatkan variabel bebas lain selain indeks waktu $(t)$ itu sendiri, sehingga mengabaikan faktor-faktor bebas lainnya, sebab yang akan diketahui adalah model perilaku data, bukan faktor apa yang menyebabkan fluktuasi data (Suhartono, 2001).

Metode yang sering digunakan dalam analisis time series adalah ARIMA. Model ARIMA mampu mewakili deret waktu stasioner maupun nonstasioner Karakteristik model ini tidak mengikutkan variabel bebas didalam modelnya. Pada ARIMA, suatu analisis time series nonstasioner harus diubah menjadi data stasioner dengan melakukan differensiasi. Differensiasi adalah menghitung perubahan atau selisih nilai observasi. Nilai selisih yang diperoleh dicek lagi apakah stasioner atau tidak.

Deteksi pencilan merupakan salah satu bidang penelitian yang penting dalam topik data mining. Penelitian ini bermanfaat untuk mendeteksi perilaku yang tidak normal seperti deteksi intrusi jaringan, diagnosa medis, dan lain-lain. Penyebab adanya outlier yaitu data berasal dari kelas yang berbeda, variasi natural data itu sendiri dan error pada saat pengukuran atau pengumpulan data. Banyak metode telah dikembangkan untuk menyelesaikan masalah ini, namun kebanyakan hanya fokus pada data dengan atribut yang seragam, yaitu data numerik atau data kategorikal saja.

Perkembangan analisis deret waktu tentang pencilan belum secepat dan seluas pada ilmu statistik secara umum. pencilan dapat mempengaruhi struktur autokorelasi dari suatu time series sehingga nilai estimasi dari autocorrelation function (ACF) dan partial autocorrelation function (PACF) yang diperoleh menjadi bias. Keberadaan pencilan akan menyesatkan ketika dilakukan identifikasi model dan peramalan, oleh karena itu perlu dilakukan penanggulangan dengan cara melakukan deteksi pencilan terlebih dahulu. Telah banyak penelitian tentang deteksi pencilan, namun penelitian tentang deteksi pencilan untuk data deret waktu musiman ganda belum diterapkan dalam perangkat lunak statistik manapun. Ini dikarenakan data yang cukup panjang akan mengalami kegagalan dalam pendeteksian karena tahapan iteratif untuk pendeteksian pencilan memerlukan representasi model Autoregressive (AR) yang cukup rumit.

Oleh karena itu, pada penelitian ini dilakukan deteksi pencilan pada model ARIMA yaitu pada data debit air di Kota Palopo menggunakan metode grafis untuk pengembangannya. Pengembangan deteksi pencilan pada analisis peramalan data debit air diharapkan akan memberikan peramalan yang lebih akurat, hal ini akan menjadi sumbangan yang cukup berarti bagi PT. PDAM (Persero) dalam memberikan pelayanan penyaluran air bersih ke konsumen.

Berdasarkan penjelasan di atas maka dapat dirumuskan permasalahan dari penelitian ini, yaitu bagaimana model peramalan yang sesuai untuk mengatasi adanya pencilan pada debit air Kota Palopo menggunakan Model ARIMA Deteksi Pencilan. 
Tujuan dari penelitian ini adalah menentukan model peramalan yang sesuai untuk mengatasi adanya pencilan pada debit air Kota Palopo menggunakan Model ARIMA Deteksi Pencilan. Batasan masalah pada Penelitian ini adalah data debit air PT. PDAM Kota Palopo Tahun 2010-2015 dan model ARIMA deteksi pencilan.

\section{METODE}

Penelitian ini menggunakan data debit air di Kota Palopo periode bulan Januari 2010 sampai dengan bulan Desember 2015 dengan jumlah data 72 yang diperoleh dari PT. PDAM Kota Palopo. Tahapan-tahapan dalam pembentukan model ARIMA pada data debit air Kota palopo yaitu:

a) Identifikasi, pertama-tama, lakukan identifikasi model ARIMA pada data debit air Kota palopo, dengan membuat plot data deret waktu, plot ACF, dan plot PACF. Adapun langkah-langkah pada tahap identifikasi ini adalah:

1) Plot data deret waktu, ACF, dan PACF dari data debit air Kota palopo yang ingin dimodelkan. Dari ketiga plot ini, dapat dilihat apakah data ada yang telah stasioner atau belum.

2) Apabila pada tahap sebelumnya terlihat bahwa data masih belum stasioner pada varians, hal ini dapat diatasi dengan menggunakan transformasi box-cox.

3) Apabila data masih belum stasioner pada mean, maka perlu untuk dilakukan differencing pada data.

b) Estimasi parameter, setelah menetapkan identifikasi model sementara, parameterparameter yang digunakan pada model ARIMA diestimasi dengan Maximum Likelihood Estimation (MLE). Setelah parameter diestimasi, maka lakukan uji signifikansi parameter yang menggunakan statistik uji $t$.

c) Pemeriksaan diagnostik, tahap ini terdiri atas dua sub-tahap yaitu:

1. Uji kenormalan galat yang menggunakan statistik uji Kolmogorov-Smirnov.

2. Uji kecukupan model yang menggunakan statistik uji $Q$.

d) Pemilihan model terbaik berdasarkan nilai MSE.

e) Tahapan deteksi pencilan.

Hasil uji normalitas residual menunjukkan bahwa residual model ARIMA belum white noise, dan mengindikasikan adanya outlier pada data. Sehingga, langkah selanjutnya yang dilakukan adalah deteksi outlier untuk mengeliminasi efek outlier dan memperbesar ketepatan prediksi dari model ARIMA. Implementasi pemodelan ARIMA dan deteksi outlier dilakukan dengan menggunakan SAS.

\section{HASIL DAN PEMBAHASAN}

Model ARIMA diawali dengan membuat plot deret waktu dari data Debit air Kota Palopo Tahun 2010-2015 yang dapat dilihat pada Gambar 1. Plot tersebut digunakan untuk mengetahui stasioneritas baik terhadap varians maupun mean. 


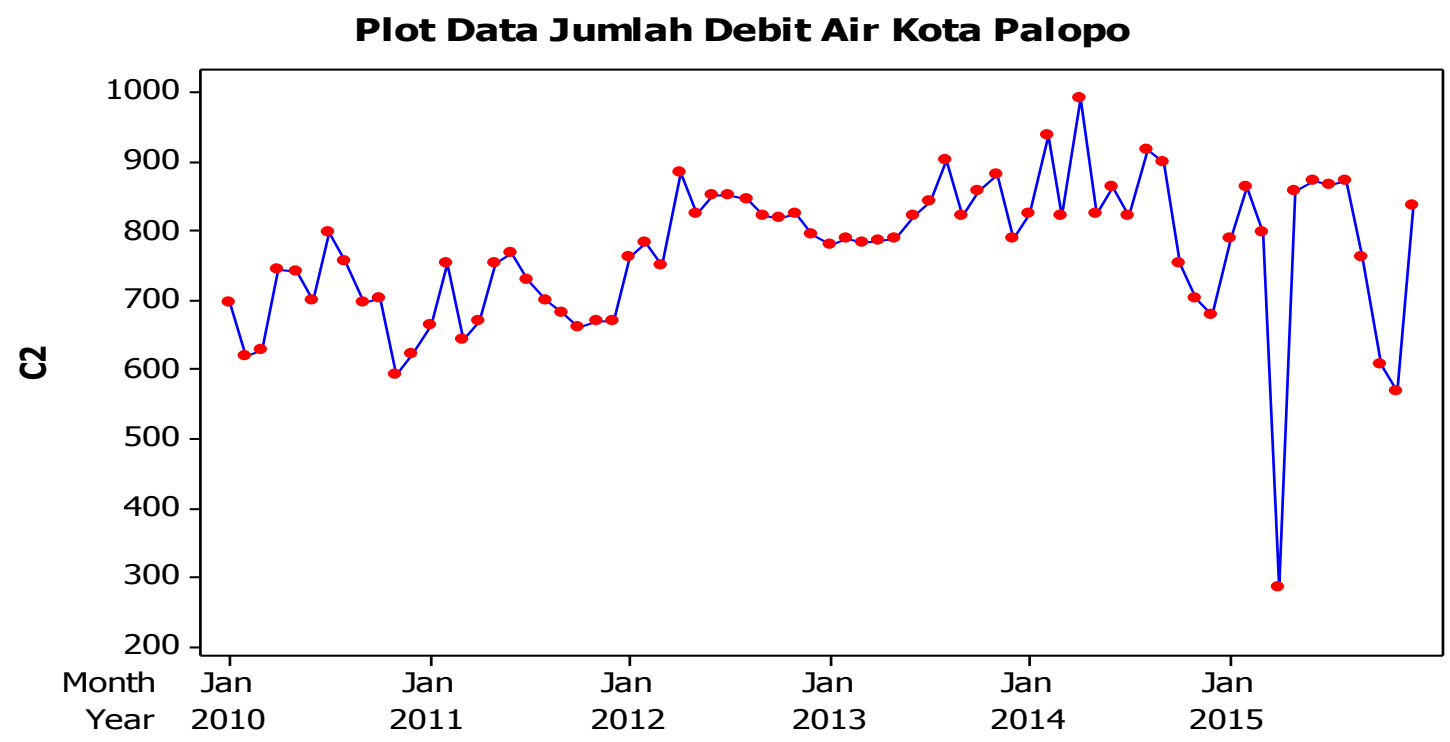

Gambar 1. Plot Debit Air PDAM Kota PalopoTahun 2010-2015

Plot Debit Air PDAM Kota Palopo Tahun 2010-2015 yang ditunjukkan oleh Gambar 1 mengindikasikan bahwa tidak stasioner dalam mean tetapi belum stasioner dalam varians. Indikasi tersebut diperkuat dari plot ACF data Debit Air berikut ini (Lihat Gambar 2):

Autocorrelation Function for $\mathbf{C 2}$

(with $5 \%$ significance limits for the autocorrelations)

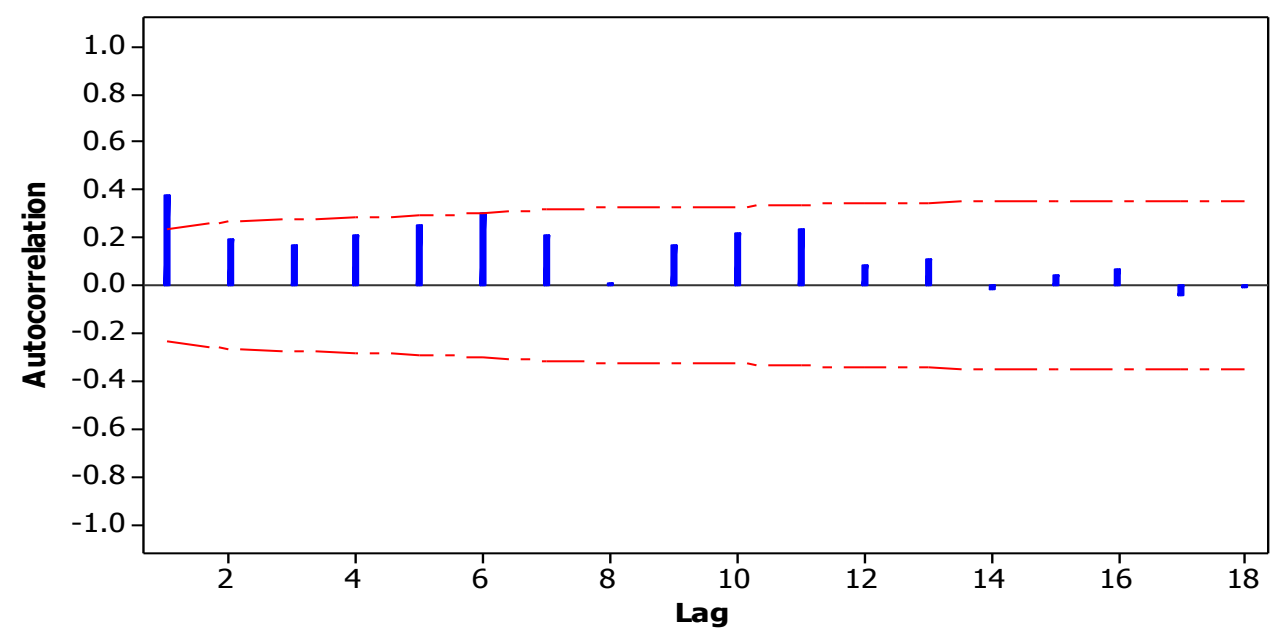

Gambar 2. Plot ACF Debit Air PDAM Kota Palopo Tahun 2010-2015

Berdasarkan plot ACF dan PACF data menunjukkan indikasi model bukan deret waktu musiman. Selanjutnya dilakukan proses transformasi untuk menstasionerkan data dalam varians. Seperti yang terlihat pada Gambar 2 . 


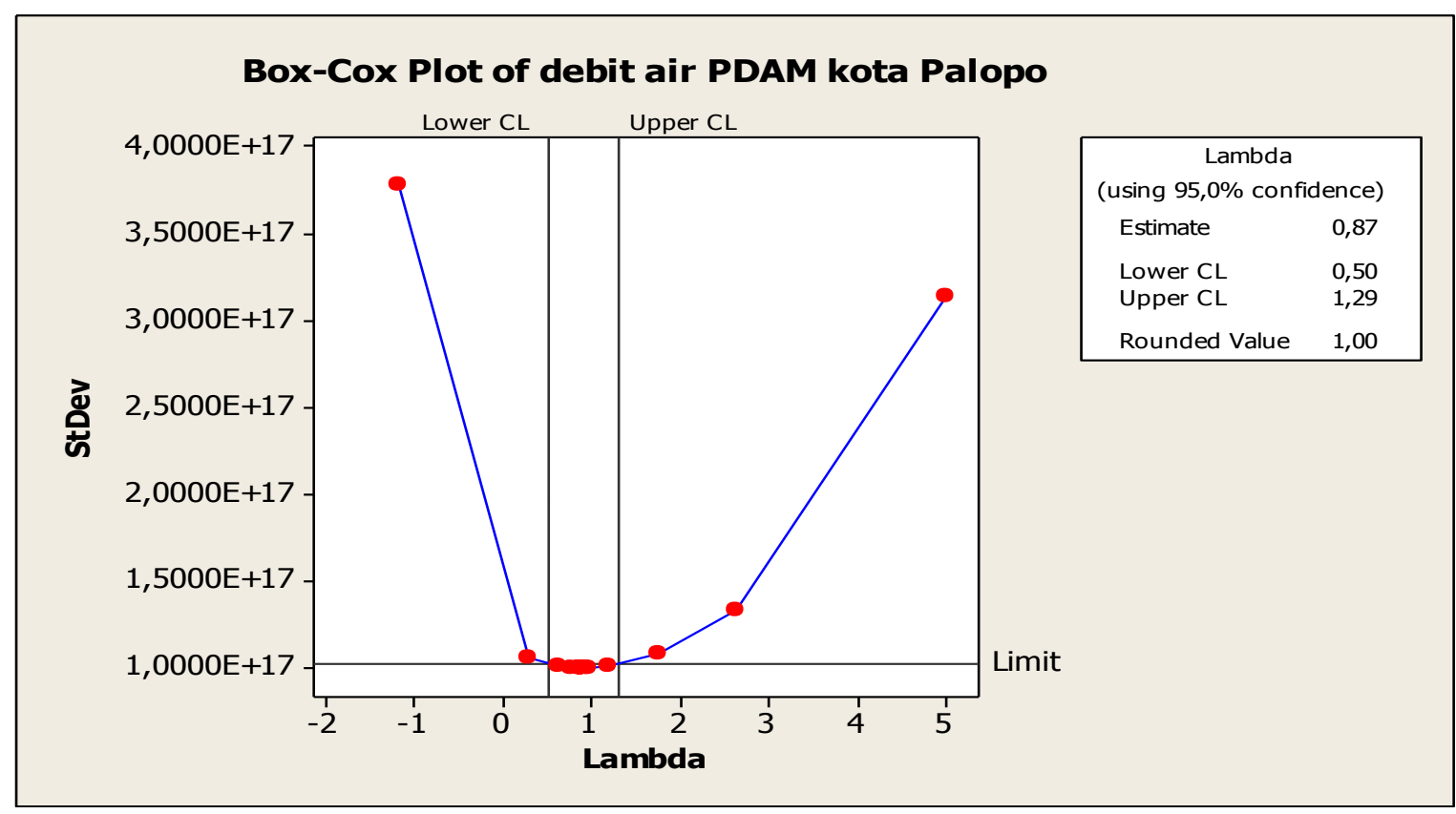

Gambar 3. Plot Transformasi Box-Cox Debit Air PDAM Kota Palopo Tahun 2010-2015

Transformasi yang diguanakan adalah transformasi Box-Cox. Untuk melihat data sudah stasioner yaitu, dilihat dari nilai rounded value. Jika nilai rounded value bukan 0 atau nilai rounded value $>0$ maka data sudah stasioner dalam varians. Seperti dilihat pada Gambar 3.

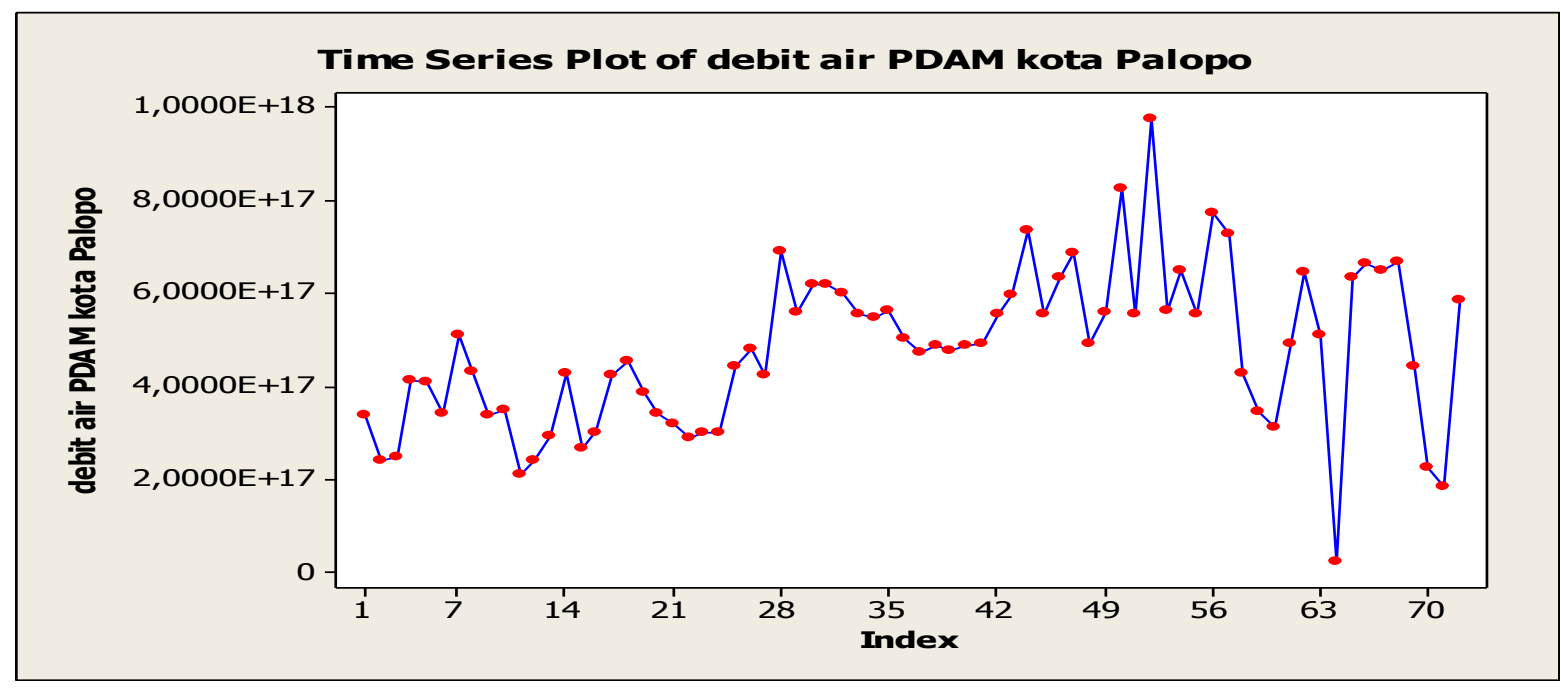

Gambar 4. Plot Debit Air PDAM Kota Palopo setelah di Transformasi Tahun 2010-2015

Untuk mendapatkan plot stasioner yang lebih baik maka dilakukan differencing 1 kali, sehingga diperoleh hasil seperti pada Gambar 4. 


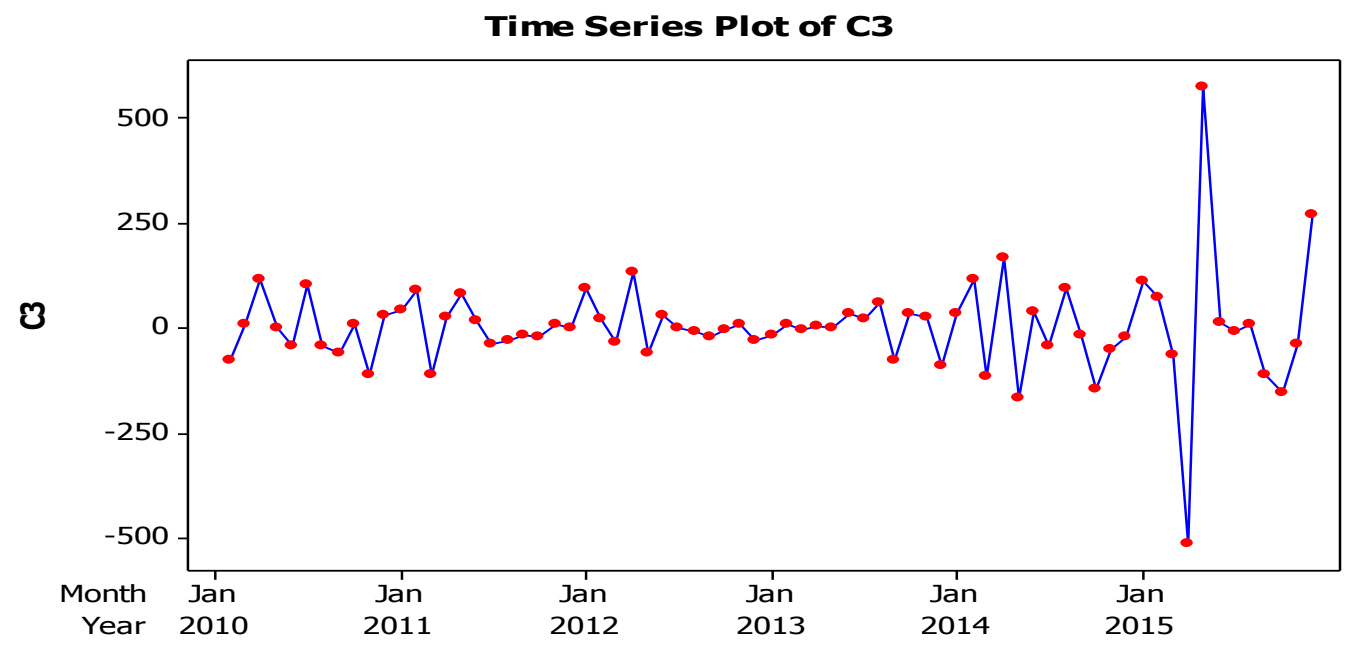

Gambar 5. Plot Debit Air PDAM Kota Palopo Differencing Tahun 2010-2015

Plot deret waktu Debit Air PDAM Kota Palopo Tahun 2010-2015 setelah dilakukan differencing ditunjukan oleh Gambar 5 mengindikasikan bahwa sudah stasioner dalam mean dan juga stasioner dalam varians.

Parameter-parameter model ARIMA untuk data Debir Air PDAM Kota Palopo Tahun 2010-2015 yang telah melalui proses penstasioneran akan diestimasi. Tabel 1 menyajikan 3 buah model dugaan ARIMA yang memenuhi uji signifikansi parameter.

Tabel 1. Estimasi dan uji signifikansi model ARIMA

\begin{tabular}{lccccc}
\hline $\begin{array}{l}\text { Model } \\
\text { ARIMA }\end{array}$ & Parameter & Estimasi & $\begin{array}{c}\text { Standard } \\
\text { error }\end{array}$ & t-value & p-value \\
\hline$(1,1,0)$ & $\phi_{1}$ & 0,1893 & 0,1520 & 1,25 & 0,217 \\
& $\Phi_{1}$ & 0,8836 & 0,0779 & 11,34 & 0,001 \\
$(0,1,1)$ & $\Phi_{1}$ & 0,8152 & 0,0698 & 11,68 & 0,001 \\
& $\phi_{1}$ & 0,1740 & 0,1489 & 1,17 & 0,247 \\
& $\Theta_{1}$ & 0,8676 & 0,0750 & 11,57 & 0,001 \\
\hline
\end{tabular}

Hasil estimasi dan uji signifikansi parameter dapat dilihat pada tabel 2. Model yang diduga telah memenuhi signifikansi parameter dengan nilai $p$-value dari parameter lebih kecil dari taraf signifikansi 5\%.

Langkah selanjutnya adalah melakukan uji diagnostic dari model ARIMA yang terbentuk. Uji diagnostik dilakukan untuk mengetahui apakah model ARIMA yang terbentuk memenuhi asumsi residual white noise dan berdistribusi normal. Pengujian asumsi white noise dari model tersebut dapat dilihat pada Tabel 2.

Tabel 2. Uji white noise model ARIMA

\begin{tabular}{cclll}
\hline Model ARIMA & Lag & Chi-square & $p$-value & Keterangan \\
\hline \multirow{3}{*}{$(1,1,0)$} & 12 & 9,9 & 0,03 & \\
& 24 & 14,3 & 0,856 & Tidak White Noise \\
& 36 & 19,0 & 0,975 & \\
\hline
\end{tabular}




\begin{tabular}{lllll}
\hline & 12 & 12,7 & 0,03 & \\
$(0,1,1)$ & 24 & 16,9 & 0,813 & Tidak White Noise \\
& 36 & 21,8 & 0,960 & \\
& 48 & 28,6 & 0,984 & \\
$(1,1,1)$ & 12 & 10,2 & 0,420 & \\
& 24 & 14,7 & 0,877 & White Noise \\
& 36 & 19,0 & 0,982 & \\
\hline
\end{tabular}

Pemilihan model ARIMA terbaik dilakukan dengan menggunakan nilai MSE seperti pada Tabel 3, di bawah. Nilai ARIMA yang memiliki nilai MSE terkecil dipilih sebagai model terbaik.

Tabel 3 Kriteria pemilihan model terbaik ARIMA Model ARIMA MSE

$$
(1,1,1)
$$
9579

Berdasarkan Tabel 4, maka model terbaik untuk data Debit Air PDAM Kota Palopo adalah model ARIMA $(1,1,1)$ yang memiliki nilai MSE lebih kecil. Berdasarkan hasil analisis menggunakan program SAS, maka diperoleh pencilan sebagai berikut:

Tabel 4 Jenis outlier pada data Debit Air

\begin{tabular}{ccc}
\hline Observasi & Jenis outlier & Jumlah Debit Air \\
\hline 64 & Additive & 284948 \\
72 & Additive & 836784 \\
70 & Shift & 606442 \\
58 & Shift & 753128 \\
52 & Additive & 991056 \\
50 & Additive & 937440 \\
61 & Shift & 789091 \\
\hline
\end{tabular}

Berdasarkan Tabel 4 di atas, maka diperoleh bahwa terdapat tujuh pencilan pada data debit air di kota Palopo. Data observasi 64 tercatat sebagai jumlah debit air pada bulan April Tahun 2015 sebanyak 284948. Nilai ini memang sangat jauh dari rata-rata observasi sehingga dapat dikategorikan sebagai data yang menyimpang. Begitupun juga dengan observasi ke 72 yang terjadi pada Tahun 2015 dengan nilai debit air sebanyak 836784. Nilai ini juga termasuk nilai tinggi daripada rata-ratanya. Hal ini berbeda pada observasi ke 64 karena pada observasi tersebut justru memiliki nilai rendah dari data pada umumnya. Untuk observasi outlier dengan nilai debit air tertinggi ada pada data 52 yaitu 991056. Data ke 52 merupakan data yang tercatat pada bulan April Tahun 2014. Berdasarkan analisis sebelumnya, bahwa model ARIMA terbaik adalah ARIMA $(1,1,1)$ dengan bentuk matematis sebagai berikut:

atau

$$
(1-0,174 B)(1-B) Z_{t}=(1-0,075 B) a_{t}
$$

$$
y_{t}=\frac{(1-0,075 B)}{(1-0,174 B)(1-B)} a_{t}
$$

Hasil estimasi outlier pada kasus debit air Kota Palopo sebagai berikut (Lihat Tabel 5): 
Tabel 5 Estimasi outlier pada data Debit Air

\begin{tabular}{ccc}
\hline Observasi & Jenis outlier & Estimasi \\
\hline 64 & Additive & 5620130,9 \\
72 & Additive & 2544443,4 \\
70 & Shift & 203794,9 \\
58 & Shift & $-168149,0$ \\
52 & Additive & 130702,3 \\
50 & Additive & 113680,4 \\
61 & Shift & 127748,3 \\
\hline
\end{tabular}

Dari jumlah outlier tersebut kemudian dilakukan estimasi untuk data debit air setelah penambahan outlier. Estimasi parameter model ARIMA (1,1,1) dengan penambahan outlier sebanyak 7 dapat dilihat pada Tabel 6 berikut:

Tabel 6 Estimasi parameter ARIMA $(1,1,1)$ setelah penambahan outlier

\begin{tabular}{ccccc}
\hline Parameter & Estimasi & Standard error & t-value & p-value \\
\hline $\boldsymbol{\mu}$ & 759015.1 & 25621.8 & 29.62 & $<.0001$ \\
$\boldsymbol{\phi}_{\mathbf{1}}$ & -0.17413 & 0.17821 & -0.98 & 0.3323 \\
$\boldsymbol{\theta}_{\mathbf{1}}$ & 0.69054 & 0.13609 & 5.07 & $<.0001$ \\
$\boldsymbol{T}_{\mathbf{6 4}}$ & -532958 & 46323.7 & -11.51 & $<.0001$ \\
$\boldsymbol{T}_{\mathbf{7 2}}$ & 227455.9 & 64205.9 & 3.54 & 0.0008 \\
$\boldsymbol{T}_{\mathbf{7 0}}$ & -50333.1 & 46341.6 & -1.09 & 0.2816 \\
$\boldsymbol{T}_{\mathbf{5 8}}$ & -45096.4 & 45752.4 & -0.99 & 0.3281 \\
$\boldsymbol{T}_{\mathbf{5 0}}$ & 185265.2 & 47335.5 & 3.91 & 0.0002 \\
$\boldsymbol{T}_{\mathbf{6 1}}$ & 14125.5 & 45842.6 & 0.31 & 0.759 \\
\hline
\end{tabular}

Berdasarkan Tabel 6 di atas terlihat bahwa ada beberapa parameter yang tidak signifikan. Parameter yang signifikan dapat diambil untuk dimasukan ke dalam model ARIMA dengan deteksi outlier. Adapun model ARIMA dengan penambahan outlier dapat ditulis sebagai berikut:

$y_{t}=\frac{(1-0.69054 B)}{(1-B)} a_{t}-532958 T_{64}+227455.9 T_{72}-\frac{50333.1}{(1-B)} T_{70}-\frac{45096.4}{(1-B)} T_{58}+\frac{185265.2}{(1-B)} T_{50}$

Model tersebut memberikan nilai MSE untuk ARIMA deteksi outlier sebesar 6081,050. Nilai ini lebih kecil dibandingkan dengan nilai MSE yang diperoleh tanpa deteksi outlier yaitu 9579.

Hasil ramalan menggunakan model ARIMA deteksi outlier dapat dilihat pada Gambar 7 berikut: 


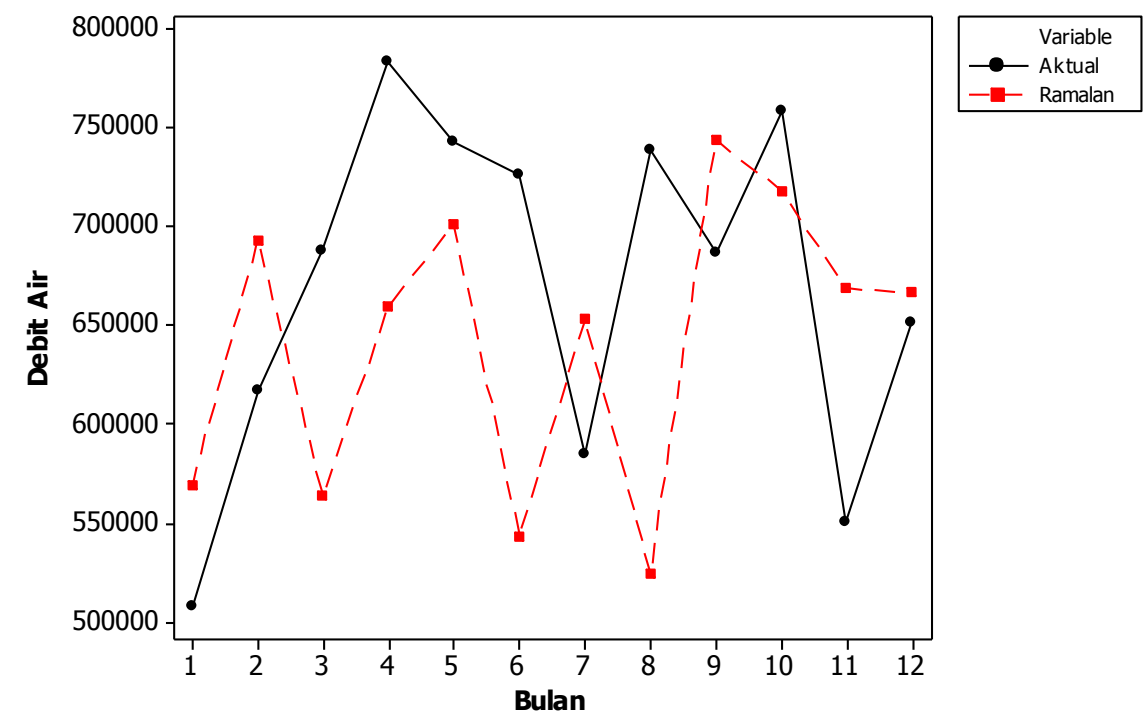

Gambar 7. Ramalan debit air Kota Palopo

\section{KESIMPULAN}

Berdasarkan hasil analisis data debit air Kota Palopo menggunakan model ARIMA deteksi outlier maka dapat disimpulkan bahwa model ARIMA debit air yang terbaik adalah model sebagai berikut

$$
Z_{t}=\frac{(1-0.69054 B)}{(1-B)} a_{t}-532958 T_{64}+227455.9 T_{72}-\frac{50333.1}{(1-B)} T_{70}-\frac{45096.4}{(1-B)} T_{58}+\frac{185265.2}{(1-B)} T_{50}+14125.5 T_{61}
$$

\section{REFERENSI}

Bowerman, B.L., R.T. O'Connell, and A.B. Koehler. 2005. Forecasting, Time Series, and Regression: An Applied Approach, Edisi Keempat. Brooks/Cole. Boston.

Damayanti. 2008 Pengertian analisis deret waktu dan metode model ARIMA.

Suhartono, B. W. 2001. Laporan Penelitian: Penerapan dan Perbandingan Model Intervensi dan Model Fungsi Transfer untuk Analisis Faktor-faktor yang Berpengaruh terhadap Jumlah Penumpang Kereta Api dan Pesawat Udara Jurusan Surabaya-Jakarta. Lembaga Penelitian Institut Teknologi Sepuluh November. Surabaya.

Wei,W.W.S. 1994. Time Series Analysis: Univariate and Multivariate Methods, Second Edition. Addison-Wesley Publishing, Co. Canada. 